\title{
Alianse wiedzy i ich wpływ na działalność innowacyjną przedsiębiorstwa
}

\section{Anna Karaś}

Małopolska Wyższa Szkoła Ekonomiczna w Tarnowie

E-mail:

anna.karas@mwse.edu.pl ORCID: 0000-0002-5688-3389
Publikacja sfinansowana przez: Małopolska Wyższa Szkoła Ekonomiczna w Tarnowie

Correspondence to:

Anna Karaś

Małopolska Wyższa Szkoła

Ekonomiczna w Tarnowie,

ul. Waryńskiego 14,

33-100Tarnów, Poland

Telefon: + 48146565535

\begin{abstract}
Abstrakt: Celem artykułu jest przedstawienie motywów zawierania aliansów między podmiotami oraz próba ukazania ich wpływu na innowacyjność i działalność innowacyjną przedsiębiorstwa. W pierwszej części artykułu zaprezentowano dyskusję na temat pojęć związanych z innowacyjnością i potencjałem innowacyjnym przedsiębiorstwa, jak również klasyfikację, cechy i cele współpracy w ramach aliansów strategicznych. $\mathrm{W}$ artykule przyjęto, iż potencjał innowacyjny przedsiębiorstwa to zespół cech społeczno-gospodarczych, kształtowanych w ramach rozwoju danego przedsiębiorstwa, stanowiących bazę dla jego działalności innowacyjnej. Silny wpływ na innowacyjność przedsiębiorstwa ma również jego otoczenie sektorowe, tj. klienci, konkurenci czy kooperanci oraz łączące ich relacje. Oceną zaś stopnia prowadzonej działalności innowacyjnej jest liczba wdrożonych innowacji, rodzaj innowacji czy uzyskane wartości z innowacji. W drugiej części artykułu przedstawiono wyniki analizy metodą case study. W zaprezentowanych przykładach przedsiębiorstw działalność innowacyjna jest wynikiem prowadzenia efektywnej współpracy z innymi podmiotami poprzez zawieranie aliansów łączenia sił lub aliansów wiedzy. Dzięki aliansom przedsiębiorstwa mają możliwość poszerzania własnego potencjału innowacyjnego, pozyskiwania wiedzy niezbędnej do tworzenia innowacji oraz budowania pozycji rynkowej.
\end{abstract}

Słowa klucze: alianse wiedzy, innowacje, potencjał innowacyjny, zdolność innowacyjna

\section{Uwagi wstępne}

W dobie zmieniającej się rzeczywistości gospodarczej oraz rozwoju społecznego przedsiębiorstwa, jako systemy otwarte, muszą dostosować się do zachodzących w gospodarce zmian. Każda zmiana może być rozpatrywana dwojako: jako szansa lub zagrożenie. W zależności od czasu i stopnia reakcji na zmienność otoczenia, poszczególne przedsiębiorstwa mogą wykorzystać tę sytuację jako odpowiedni czas dla własnego rozwoju oraz budowania pozycji rynkowej. Jednym z najważniejszych czynników wpływających na konkurencyjność 
i rozwój przedsiębiorstwa jest wiedza, która odpowiednio ukierunkowana staje się podstawą tworzenia innowacji. To właśnie innowacja stanowi o rozwoju przedsiębiorstwa, branży oraz gospodarki w ujęciu globalnym.

Przyjmując, iż innowacja jest to wszelka, z założenia korzystna, twórcza i oryginalna zmiana w różnych obszarach działalności organizacji, wnosząca nowość i postęp w stosunku do stanu istniejącego, ocenianego pozytywnie w świetle kryteriów efektywności danej organizacji (Kozioł, Wojtowicz, Karaś, 2017), należy zastanowić się nad źródłem wiedzy, dzięki któremu innowacja powstaje. Przedsiębiorstwa mogą korzystać z wewnętrznych oraz zewnętrznych źródeł wiedzy. Do wewnętrznych źródeł możemy zaliczyć m.in. kreatywność i stan wiedzy pracowników wszystkich szczebli czy posiadane przez przedsiębiorstwo bazy danych. Zewnętrzne źródła wiedzy obejmują informacje pochodzące $\mathrm{z}$ otoczenia przedsiębiorstwa, czyli np. klientów, dostawców, konkurencyjnych przedsiębiorstw czy też ośrodków naukowo-badawczych (Karaś, Pyrek, 2012).

Najważniejszymi źródłami wiedzy zewnętrznej według Probsta, Rauba i Romhardta (2004) jest:

- zatrudnianie specjalistów w celu wykorzystania ich umiejętności w procesie wytwarzania wyrobów i świadczenia usług,

- współpraca $\mathrm{z}$ innymi przedsiębiorstwami w ramach różnorodnych form współpracy (przejęcia, alianse strategiczne, alianse oparte na powiązaniach produktowych, alianse oparte na wiedzy),

- wiedza pochodząca od uczestników rynku (klienci, dostawcy, udziałowcy, pracownicy i reprezentujące ich organizacje, rynki finansowe, politycy, środki masowego przekazu i osoby kształtujące opinię publiczną, społeczeństwo),

- produkty związane z wiedzą (zakup oprogramowania, zakup baz danych, nabywanie praw do własności intelektualnej itp.).

Przedsiębiorstwo musi jednak wykazać się odpowiednimi zdolnościami w zakresie efektywnego pozyskania wiedzy z otoczenia, która odpowiada specyfice i realizowanym przez przedsiębiorstwo celom, oraz zostanie przez nie skutecznie wykorzystana w prowadzonej działalności innowacyjnej.

O skali działalności innowacyjnej decyduje posiadany przez przedsiębiorstwo potencjał innowacyjny. W niniejszym artykule przyjęto, iż potencjał innowacyjny przedsiębiorstwa to zespół cech społeczno-gospodarczych, kształtowanych w ramach rozwoju danego przedsiębiorstwa, stanowiących bazę dla jego działalności innowacyjnej. W głównej mierze są to zasoby, procesy, struktury, czynniki występujące w przedsiębiorstwie. Jednakże nie tylko one decydują o skali potencjału innowacyjnego, również silny wpływ ma właśnie otoczenie sektorowe, a więc przedsiębiorstwo wraz z klientami, konkurentami, dostawcami i kooperantami oraz relacje, jakie łączą przedsiębiorstwo z jego najważniejszymi interesariuszami. W takim ujęciu można rozpatrywać innowację jako aktywność relacyjną, gdy relacje te zachodzą między jednostkami, jednostkami i technologią, jednostkami i firmami, firmami i innymi podmiotami gospodarczymi, agencjami badawczymi czy instytucjami państwowymi (Hall, Williams, 2008, s. 23).

Wykorzystanie potencjału innowacyjnego w sposób efektywny oznacza, iż przedsiębiorstwo posiada zdolność innowacyjną (innowacyjności), która obejmuje kreatywny proces tworzenia innowacji w organizacji. W oparciu o prowadzone badania oraz literaturę przed- 
miotu dotyczącą innowacyjności, jako kluczowe determinanty budowy i rozwoju zdolności innowacyjnej przyjęto: kompetencje kierownicze i pracownicze - zwłaszcza wiedza z doświadczenia i wiedza pozyskana z zewnątrz, nowoczesność infrastruktury, organizację pracy, kooperację w zarządzaniu wiedzą ( $\mathrm{tj}$. budowanie aliansów wiedzy z klientami i innymi podmiotami oraz dodatkowo korzystanie z otwartych źródeł wiedzy lub zakup technologii) oraz zabezpieczenie wiedzy (Kozioł, Wojtowicz, Pyrek, 2014; Gault, 2018; Von Hippel, 2016).

Obecne realia gospodarcze wymuszają na przedsiębiorstwach podejmowanie dużego wysiłku, by nie tylko uzyskać przewagę rynkową, ale w ogóle na tym rynku istnieć. Tym samym przedsiębiorstwa, zwłaszcza w sektorze małych i średnich przedsiębiorstw, otwierają się na współpracę z jednostkami zewnętrznymi, aby móc prowadzić działalność innowacyjną.

Celem artykułu jest prezentacja motywów zawierania aliansów między podmiotami oraz ukazanie ich wpływu na innowacyjność i działalność innowacyjną przedsiębiorstwa. W artykule zaprezentowano również wyniki analizy case study przedsiębiorstw prowadzących działalność innowacyjną w oparciu o alianse, zwłaszcza alianse wiedzy.

\section{Alianse przedsiębiorstwa - istota i rodzaje}

Przedsiębiorstwo prowadząc swoją działalność gospodarczą przyjmuje własną strategię działania w pozyskiwaniu wiedzy niezbędnej w procesie innowacji. Z powodu zmienności i złożoności czynników wpływających na sytuację gospodarczą, rozwój branży, zmienność otoczenia organizacji, przedsiębiorstwa częściej decydują się na zawieranie porozumień nazywanych aliansami.

W literaturze przedmiotu można spotkać wiele definicji aliansu. W ogólnym ujęciu aliansem można nazwać związek między przedsiębiorstwami, którego zamierzeniem jest zrealizowanie przez partnerów wspólnego celu (Morris, Hergert, 1987). Garrette i Dussauge (1996) określają alians strategiczny jako porozumienie między dwoma lub większą ilością przedsiębiorstw, zawiązywane w celu realizacji wspólnego projektu lub prowadzenia specyficznej działalności, dzięki któremu mogą koordynować kompetencje i zasoby, zmniejszając ponoszone ryzyko. $Z$ kolei Romanowska definiuje to pojęcie podając, iż „alians strategiczny to współpraca między aktualnymi lub potencjalnymi konkurentami, mająca wpływ na sytuację innych konkurentów, dostawców lub klientów w obrębie tego samego lub pokrewnych sektorów" (Romanowska, 1997, s. 15).

Ważną cechą aliansów jest to, że podkreślają niezależność podmiotów, które ze sobą współpracują. Alianse strategiczne są ,jednostkowymi aktami, umowami o współpracę między potencjalnymi lub bezpośrednimi konkurentami” (Cygler, 2009, s. 17), charakteryzujące się długoterminowością i celowością. ,Zawarte są one na zasadach partnerstwa i adekwatności czerpanych z sojuszu korzyści, przy zachowaniu odrębności organizacyjnej stron układu" (Cygler, 2002, s. 33).

W zasadzie pojawiające się w literaturze definicje aliansu łączy występowanie cech, na jakie zwrócili uwagę Yoshino i Rangan (1995, s. 5), według których alians może przybierać różne formy prawne, ale musi równocześnie spełniać trzy konieczne warunki:

- współpracujące ze sobą firmy - dwie lub więcej - dążące do realizacji uzgodnionych celów pozostają niezależne po zawarciu aliansu, 
- firmy dzielą ze sobą korzyści aliansu i wspólnie kontrolują wykonanie przypisanych im zadań,

- firmy partnerskie na bieżąco wnoszą wkład w jeden lub więcej obszarów strategicznych, np. rozwój technologii lub produktów.

Bazując na literaturze przedmiotu można wyróżnić różne kryteria podziału aliansów, jednak do najczęściej występujących kryteriów podziału należy wymienić podział ze względu na formy organizacyjno-prawne oraz relacje konkurencyjne między partnerami.

Dokonując podziału aliansów pod kątem formy organizacyjno-prawnej możemy wyróżnić alianse formalne i nieformalne. Do formalnych zaliczamy (Romanowska, 1997, s. 83):

- alianse udziałowe w postaci spółek joint venture i podobnych,

- alianse bezudziałowe umowne: licencja, franchising, umowa o współpracy, umowa o stowarzyszeniu,

- alianse bezudziałowe kapitałowe: udziały mniejszościowe, wzajemny wykup udziałów.

Wśród aliansów nieformalnych znajdują się porozumienia tzw. milczące, których celem są działania niezgodne z prawem (np. próba obejścia przepisów antymonopolowych) lub działania zmierzające do wyeliminowania konkurencji z rynku, skierowane przeciwko innym przedsiębiorstwom (tzw. układ o „wspólnym eliminowaniu konkurenta”) (Kuraś, 2012). Wybór współpracy sformalizowanej zapewnia partnerom aliansu poczucie większego bezpieczeństwa niż współpraca niesformalizowana. W przypadku braku zapisów warunków współpracy mogą pojawić się sytuacje konfliktowe, spowodowane niemożliwością sprawdzenia, jaki był przedmiot i zakres umowy między partnerami. Każda z powyższych kategorii różni się innym stopniem i rodzajem kontroli nad współpracą oraz innym zaangażowaniem.

Drugim ważnym kryterium podziału jest ten ze względu na relacje łączące partnerów aliansu i tutaj wyróżnia się (Garette, Dussauge, 1996, s. 17):

- alianse między przedsiębiorstwami konkurencyjnymi: ścisłej integracji, addytywne, komplementarne,

- alianse między przedsiębiorstwami niekonkurencyjnymi: partnerstwo wertykalne, międzynarodowe spółki joint venture, porozumienia międzysektorowe.

W tej klasyfikacji należy zwrócić uwagę na fakt, iż współpracę podejmują nie tylko przedsiębiorstwa, których działalność w pewnych obszarach staje się uzupełnieniem, ale również współpracę podejmują przedsiębiorstwa, które są dla siebie konkurentami. Oczywistą przyczyną nawiązania współpracy w ramach aliansu jest współpraca polegająca na uzupełnianiu własnych działań, realizacji zadań $\mathrm{w}$ wybranym zakresie. Z kolei nawiązanie współpracy między mniej lub bardziej bezpośrednimi konkurentami już nie jest tak oczywiste. Współpraca ta jednak jest podejmowana w celu uzyskania większych korzyści lub określonych efektów synergicznych, przy jednoczesnym ograniczeniu konkurencji między sobą.

Oprócz wyżej wspomnianej klasyfikacji można również wyodrębnić klasyfikację aliansów ze względu na motywy podejmowania współpracy (Romanowska, 2017). W tym przypadku wyróżnia się alianse rozwoju rynku (np. relacje przedsiębiorstw szukających partnera o międzynarodowym zasięgu dystrybucji, jak i sytuacje, gdy korporacje starają się pozyskać nowy rynek), alianse dywersyfikacji (zawiązywane są w celu uzupełnienia oferty o produkty lub usługi komplementarne) oraz alianse technologiczne (wymiana lub rozwój nowej technologii). Wśród motywów zawierania aliansów wskazywane są m.in.: motywy marketingowe, które 
mogą być stosowane do pojedynczych aliansów, jak i do coraz częściej pojawiających się portfeli aliansów marketingowych. Do głównych motywów aliansów marketingowych zalicza się zwiększenie stopnia znajomości marki dzięki powiązaniu ze znaną marką partnera aliansu, kształtowanie pożądanego wizerunku marki dzięki przeniesieniu wizerunku z marki partnera aliansu, zwiększenie stopnia wyróżnienia się spośród konkurentów, zwiększenie lojalności dotychczasowych nabywców i pozyskanie nowych czy też stworzenie lepszej dostępności produktów dla nabywców dzięki zwiększeniu intensywności dystrybucji (Sznajder, 2019).

Motywy zawierania aliansów między przedsiębiorstwami są różne, jednak za podjęciem takiej decyzji przemawia: minimalizacja ponoszonych kosztów, poprawa jakości produktu, optymalizacja czasu realizacji czy pozyskanie wiedzy w celu tworzenia innowacji. Dzięki tym czynnikom, jak: koszty, jakość, wiedza, czas oraz płynność finansowa (Moszkowicz, 2000) przedsiębiorstwa mogą ze sobą skutecznie konkurować i to one wpływają na określenie, $w$ jakim celu zostają zawierane alianse.

Według J. Badaracco (1991) do najważniejszych celów aliansu strategicznego należy:

- redukcja kosztów,

- redukcja ryzyka,

- szybkie opanowanie rynku,

- zwiększenie elastyczności,

- obserwowanie konkurentów,

- sterowanie przepływem wiedzy,

- osłabianie konkurentów.

Jak podaje Glinkowska (2010, s. 230-231) wskazane cele nie straciły na ważności, natomiast można je rozszerzyć o dodatkowe, takie jak:

- połączenie wiedzy uczestników przedsiębiorstw aliantów, mające wpływ na lepsze i szybsze wprowadzenie produktu innowacyjnego,

- skorzystanie na nowszych technologiach,

- podzielenie się kosztami w przypadku niemożliwości zrealizowania planu przez jedno przedsiębiorstwo,

- podniesienie barier wejścia,

- zwiększenie efektywności organizacyjnej w dłuższej perspektywie czasu.

Jednak, aby mówić o skuteczności aliansów, muszą wystąpić odpowiednie warunki do jego stworzenia, które dotyczą występowania synergicznych korzyści dla wszystkich uczestników porozumienia, partnerstwa we współdziałaniu oraz zgodności strategicznych celów (Kuraś, 2012, s. 59).

Ważnym, z punktu widzenia wpływu na działalność innowacyjną przedsiębiorstwa, jest podjęcie decyzji o nawiązaniu współpracy i określenie zasadniczego jej celu. W tym przypadku można wyróżnić, według podejścia zaproponowanego przez Doza i Hammela (2010, s. 25) poniższe rodzaje aliansów:

- alianse polegające na łączeniu sił,

- alianse polegające na łączeniu kompetencji,

- alianse polegające na łączeniu/przejmowaniu umiejętności (przyswajaniu wiedzy).

Alians tączenia sit oznacza częściowe osłabienie konkurencyjnych przedsiębiorstw przy jednoczesnym uzyskaniu dostępu do zasobów, których przedsiębiorstwo nie posiada. Tym 
samym pozwala to stworzyć system sieciowy wpływający na trwałość zawiązanej koalicji. W efekcie przedsiębiorstwa zwiększają skalę działalności oraz swój udział w rynku, co więcej, dysponują większą siłą przetargową wobec bliższego (konkurencyjnego) i dalszego otoczenia (makrootoczenia). Wykorzystanie wspólnie posiadanych zasobów partnerów pozwala stworzyć ofertę, która jest kontrolowana przez aliantów i prowadzi do niezależności wobec pozostałych partnerów rynkowych.

Alians taczenia kompetencji zawierany jest w celu osiągnięcia efektu synergii poprzez połączenie zasobów, umiejętności, źródeł wiedzy, kontaktów i znajomości czy pozycji w otoczeniu. Podstawą zawierania tego typu aliansu jest konieczność dostosowania się do potrzeb współczesnych nabywców, którzy zainteresowani są kompleksowymi rozwiązaniami. Pojawia się zatem trudność, wynikająca z braku odpowiedniego potencjału, która wymaga od przedsiębiorstwa posiadania bardzo zróżnicowanych umiejętności i zasobów. Podejmując współpracę opartą na łączeniu kompetencji, każdy aliant może wyspecjalizować się w danym fragmencie procesu, dodając swoje kompetencje do pozostałych.

Alians przyswajania wiedzy ma na celu przejęcie od aliantów wiedzy i umiejętności, którymi przedsiębiorstwo nie dysponuje. Ten rodzaj aliansu znacząco różni się od pozostałych, ponieważ w przypadku wiedzy i umiejętności, przejęcie tego zasobu wymaga osobistego uczestnictwa i bezpośredniej współpracy. Spowodowane jest to brakiem utrwalenia czy sformalizowania, np. poprzez procedury, instrukcje czy patenty. Zatem przejęcie i przyswojenie tych kompetencji polega na obserwacji i nauce metodą warsztatową podczas współpracy zespołów mieszanych czy też wymiany stażystów między przedsiębiorstwami.

Podkreślając znaczenie wiedzy w procesie innowacji oraz rozpatrując sposoby jej pozyskiwania z zewnątrz organizacji, można przyjąć, iż jej skutecznym sposobem pozyskania są właśnie alianse. W tym kontekście można mówić o aliansach wiedzy, których głównym celem jest ,pozyskanie nowej wiedzy, przydatnej w kolejnych etapach procesu innowacyjnego (Wojtowicz, Kozioł, 2012 s. 215). W aliansie wiedzy wykorzystywane są zasoby jego partnerów w trakcie kolektywnego uczenia się i transferu informacji oraz wiedzy w procesach innowacji zarówno wewnątrz, jak i na zewnątrz aliansu (Morrison, Mezentseff, $1997 \mathrm{~s}$. 353). Można zatem stwierdzić, iż istotą aliansów wiedzy jest uczenie się poprzez wymianę i transfer wiedzy pomiędzy firmami, które podejmują współpracę w ramach aliansu.

Biorąc pod uwagę różnorodność motywów oraz zakres korzyści płynących z zawarcia takiej współpracy, można rozpatrywać alianse wiedzy na czterech płaszczyznach jako (Gulati, 1999, s. 397-420; Gupta, Mistra, 2000, s. 77-102; Simonin, 1997, s. 1150-1174):

1. możliwość wykorzystania zdobytej wiedzy w planowaniu i zarządzaniu innymi porozumieniami w przyszłości,

2. proces wzajemnego uczenia się partnerów od siebie, prowadzący do kreowania wspólnej wartości przedsiębiorstw,

3. perspektywa uczenia się razem z przedsiębiorstwem partnerskim, zwłaszcza w sytuacji rozpoczęcia przez sojuszników nowych działalności lub zdobywania i rozwijania nowych zdolności,

4. możliwość uczenia się od partnera bez integracji z jego działaniami. 
Proces uczenia się należy postrzegać zatem jako determinanta zarządzania aliansem, a nie tylko jako motyw tworzenia aliansów strategicznych, ponieważ nabyta wiedza ma istotne znaczenie dla rozwoju podjętej współpracy. Powstałe w ten sposób tzw. kompetencje aliansu strategicznego stanowią autonomiczną wartość porozumienia, wynikającą z transferu wiedzy partnera, która może przynosić jednostronne korzyści przedsiębiorstwom w przyszłości (Drewniak, Karaszewski, 2017, s. 5). Wiedzę tę można wykorzystać, jak podkreślają autorzy, nie tylko w odniesieniu do zadań realizowanych w ramach aliansu, ale również w innych obszarach, jak np. doskonaleniu produktów czy w zdobywaniu nowych rynków.

Wiedza będąca wynikiem współpracy w ramach aliansu staje się istotnym zasobem stanowiącym wartość dla przedsiębiorstwa, której nie uzyskałoby ono bez uczestnictwa w aliansie strategicznym. Dlatego też przedsiębiorstwa muszą ostatecznie podjąć decyzję o rodzaju i zakresie aliansów, mając przede wszystkim na uwadze korzyści wynikające z podjętej współpracy w procesie tworzenia innowacji.

\section{Alianse jako źródło innowacyjności przedsiębiorstwa - case study}

Zaprezentowane poniżej przykłady przedsiębiorstw poddano analizie w celu zbadania czynników wpływających na zdolność innowacyjną. Skupiając się w artykule na czynnikach zewnętrznych, jakimi są tworzone przez przedsiębiorstwa alianse wiedzy, dokonano pogłębionej analizy przedsiębiorstw z wykorzystaniem metody case study. Celem tego badania było określenie motywów, zakresu i korzyści wynikających z zawartej współpracy w ramach aliansu.

Analiza przypadku 1: przedsiębiorstwo produkujące odzież ochronną

Firma MD BHP jest małym przedsiębiorstwem działającym w branży bezpieczeństwa i higieny pracy, prowadzącym swoją działalność od 2014 r. Przedmiotem działalności jest produkcja i sprzedaż odzieży roboczej oraz artykułów bhp. Przedsiębiorstwo MD BHP oprócz dystrybucji odzieży ochronnej i roboczej innych producentów, wprowadziło na rynek własną odzież certyfikowaną: trudnopalną, antyelektrostatyczną, kwasoochronną. Dzięki wykorzystaniu własnych środków oraz podjęciu współpracy z ośrodkiem badawczym, firma stworzyła własny produkt. Takie działanie jest przykładem zawarcia aliansu opartego na łączeniu kompetencji. Współpraca z Laboratorium Badań Metrologicznych z Instytutu Technologii Bezpieczeństwa „MORAREX” w Łodzi pozwoliła na opracowanie i komercjalizację własnego innowacyjnego produktu: ubrania antyelektrostatycznego (model MD-1), ubrania MD-2 będącego ulepszeniem poprzedniej wersji poprzez dodanie cechy trudnopalności (bezpieczne dla zawodu spawacza) oraz ubrania ochronnego posiadającego cechy kwasoochronności (MD-3). Poprzez stworzenie aliansu postały trzy certyfikowane produkty: ubranie antyelektrostatyczne, antyelektrostatyczne i trudnopalne oraz antyelektrostatyczne, trudnopalne i kwasoochronne.

Kolejnym przykładem aliansu, który zawarło analizowane przedsiębiorstwo, jest współpraca z licznymi firmami usługowymi, dzięki czemu MD PHP posiada rabaty dystrybucyjne, co pozwala na oferowanie klientom prywatnym i biznesowym produktu w niższej cenie. Firma współpracuje również z drukarniami, które zajmują się tworzeniem nadruków i haftów na odzieży, przez co klient może otrzymać asortyment z własnym logo. Opisane praktyki są przykładem prowadzenia działalności z wykorzystaniem aliansu łączenia sił. 
Dzięki aliansom przedsiębiorstwo ze zwykłego sklepu z odzieżą i akcesoriami bhp stopniowo przeobraziło się w producenta innowacyjnej odzieży ochronnej. Na początku $2014 \mathrm{r}$. zatrudniony był jeden pracownik, obecnie $\mathrm{w}$ firmie pracuje trzynaście osób (w tym krawcowe). Przedsiębiorstwo MD BHP, w porównaniu z innymi firmami na rynku, jest nastawione innowacyjnie. Posiada zdolność innowacyjną, która przejawia się wykorzystaniem własnego potencjału oraz poszukiwaniem wiedzy i zasobów przy pomocy aliansów, dzięki czemu może poszerzać działalność, a tym samym poprawiać własną pozycję konkurencyjną poprzez oferowanie produktu innowacyjnego.

Analiza przypadku 2: przedsiębiorstwo produkujące i projektujące odlewy żeliwne

Odlewnie Polskie S.A. w Starachowicach powstały ponad 25 lat temu. Początkowo przedmiotem działalności była produkcja komponentów do samochodów ciężarowych, jednak wraz z rozwojem przedsiębiorstwa rozpoczęto produkcję odlewów żeliwnych wykorzystywanych w różnych branżach o zasięgu międzynarodowym. Wymagania odbiorców, dla których przeznaczone są komponenty, spowodowały rozwój techniczno-technologiczny. Innowacje produktowe wymusiły wdrożenie innowacji procesowych, zarówno w zakresie produkcji, jak i kontroli pozostałych procesów. Utworzono Ośrodek Badawczo-Naukowy Komponentów Odlewniczych dzięki współfinansowaniu przez Unię Europejską ze Środków Europejskiego Funduszu Rozwoju Regionalnego w ramach Programu Operacyjnego Rozwój Polski Wschodniej 2007-2013. Otwarcie Ośrodka Badawczo-Naukowego pozwoliło na wzrost potencjału innowacyjnego poprzez stworzenie infrastruktury badawczo-rozwojowej oraz zatrudnienie wysokokwalifikowanej kadry. Dzięki tej inwestycji spółka poprawiła swoją konkurencyjność na rynku oraz zmniejszyła koszty wytwarzania komponentów odlewniczych, jak również zmniejszyła emisję zanieczyszczeń w obrębie przedsiębiorstw odlewniczych. Głównym celem stworzenia zaplecza badawczego było umożliwienie prowadzenia prac badawczo-rozwojowych na potrzeby własnych wdrożeń oraz dla firm z sektora branży odlewniczej. Spółka podejmując takie działanie miała na celu zdobycie pozycji lidera polskiego rynku w zakresie nowoczesnych rozwiązań dla produkcji komponentów odlewniczych oraz możliwości konkurowania na rynku europejskim.

Analizowane przedsiębiorstwo jest dobrym przykładem zawierania aliansów wiedzy poprzez prowadzenie intensywnej współpracy kadry inżynieryjno-technicznej odlewni z pracownikami naukowymi czołowych ośrodków naukowo-badawczych. Pracownicy spółki prowadzą badania wspólnie z osobami zatrudnionymi na wydziałach, katedrach, zakładach i w laboratoriach takich jednostek, jak: Akademia Górniczo-Hutnicza, Politechnika Śląska, Instytut Odlewnictwa w Krakowie, Politechnika Warszawska, Politechnika Rzeszowska, Politechnika Częstochowska oraz Instytut Technologii Eksploatacji w Radomiu. Także istotną rolę odgrywały i odgrywają instytucje koordynujące rozwój innowacji, należą do nich m.in.: Narodowe Centrum Badań i Rozwoju, Ministerstwo Nauki i Szkolnictwa Wyższego, Polska Agencja Rozwoju Przedsiębiorczości oraz Staropolska Izba Przemysłowo-Handlowa.

Za strategiczną, w ramach aliansu, należy uznać współpracę z takimi ośrodkami, jak:

- Katedra Inżynierii Stopów i Kompozytów Odlewanych, Wydział Odlewnictwa AGH (w zakresie metalurgii i odlewnictwa specjalnych stopów i kompozytów odlewanych), 
- Katedra Inżynierii Stopów i Kompozytów Odlewanych, Wydział Odlewnictwa AGH (w metalurgii i odlewnictwa specjalnych stopów i kompozytów),

- Wydział Mechatroniki i Budowy Maszyn Politechniki Świętokrzyskiej (w zakresie obróbki $\mathrm{CNC}$ ),

- Instytut Metalurgii i Inżynierii Materiałowej PAN Kraków (w zakresie fotowoltaiki i zarządzania energią),

- Instytut Odlewnictwa Kraków (także w zakresie fotowoltaiki i zarządzania energią),

- Politechnika Warszawska (w zakresie tomografii komputerowej i inteligentnych sieci neuronowych).

Przedsiębiorstwo ponadto podejmuje współpracę ze Stowarzyszeniem Technicznym Odlewników Polskich, prowadząc szkolenia dla technologów odlewni krajowych. Pozwala to na dzielenie się doświadczeniem i pogłębianiem wiedzy niezbędnej w procesie tworzenia innowacji.

Przedstawione wyniki badań pokazują, jak może wyglądać dobra współpraca w ramach aliansu wiedzy. Tworzona w ten sposób wiedza staje się dla przedsiębiorstwa zasobem wpływającym na:

- rozwój przedsiębiorstwa,

- prowadzenie działalności innowacyjnej poprzez tworzenie innowacyjnych produktów,

- rozwój kadry poprzez wymianę doświadczenia między pracownikami współpracujących podmiotów,

- zmniejszenie kosztów działalności.

Reasumując, przedsiębiorstwa, które wykazują się postawą innowacyjną, rozumieją potrzebę współpracy między różnymi podmiotami, budują efektywną komunikację wewnątrz organizacji, jak i na zewnątrz. Takie podejście stwarza warunki do rozwoju pracowników, a tym samym całej organizacji, wpływając na innowacyjność przedsiębiorstwa.

\section{Podsumowanie}

Zwiększenie zdolności innowacyjnej stanowi jedno z głównych, stale aktualnych, lecz niezwykle złożonych zadań związanych z funkcjonowaniem i rozwojem przedsiębiorstw. W praktyce ocena działalności innowacyjnej, a zatem również zdolności innowacyjnej dokonywana jest głównie przez pryzmat liczby wdrożonych innowacji, rodzaju innowacji czy uzyskanych wartości z innowacji. Jak potwierdzają zaprezentowane w artykule przykłady przedsiębiorstw, istotny wpływ na zdolność innowacyjną mają alianse zawierane między kooperantami. To dzięki tej współpracy przedsiębiorstwa mają możliwość poszerzania własnego potencjału innowacyjnego, pozyskiwania wiedzy niezbędnej do tworzenia innowacji oraz budowania pozycji rynkowej. Niezaprzeczalnie to właśnie wiedza jest tym czynnikiem, który decyduje o sile i kierunku konkurowania. Przedsiębiorstwa mogą tworzyć ten istotny zasób wewnątrz organizacji, jak również pozyskiwać go w wyniku różnych aliansów strategicznych (aliansów wiedzy). Takie działanie pozwala, w zmieniających się warunkach gospodarczych, nie tylko na przetrwanie, ale również rozwój przedsiębiorstwa. 


\section{Bibliografia}

Badaracco, J.L., Jr. (1991). The knowledge link: How firms compete through strategic alliances. Boston: Harvard Business School Press. ISBN 0875842267.

Cygler, J. (2002). Alianse strategiczne. Warszawa: Difin. ISBN 83-7251-223-X.

Cygler, J. (2009). Kooperencja przedsiębiorstw. Czynniki sektorowe i korporacyjne. Warszawa: Oficyna Wydawnicza Szkoły Głównej Handlowej. ISBN 978-83-7378-421-5.

Doz, Y.L., Hammel, G. (2006). Alianse strategiczne. Sztuka zdobywania korzyści poprzez wspótpracę. Gliwice: Helion. ISBN 9788324601561.

Drewniak, R., Karaszewski, R. (2017). Wymiana wiedzy między przedsiębiorstwami w aliansie strategicznym - rola i znaczenie łańcucha wartości wiedzy i synergicznych sieci wiedzy. Przegląd organizacji, 6(929), 3-11. DOI: 10.33141/po.2017.06.01.

Garette, B., Dussauge, P. (1996). Strategie aliansów na rynku. Warszawa: Poltext. ISBN 83-86890-06-1.

Gault, F. (2018). Defining and measuring innovation in all sectors of the economy. Research Policy, 47/3, 617-622. DOI: 10.1016/j.respol.2018.01.007.

Glinkowska, B. (2010). Alians strategiczny drogą rozwoju przedsiębiorstw. Zeszyty Naukowe Uniwersytetu Przyrodniczo-Humanistycznego w Siedlcach. Seria: Administracja i Zarzadzanie, 87, 225-235.

Gulati, R. (1999). Network Location and Learning: The Influence of Network Resources and Firm Capabilities on Alliance Formation. Strategic Management Journal, 20(5), 397-420.

Gupta, A., Mistra, L. (2000). The Value of Experiential by Organizations: Evidence from International Joint Ventures. Journal of Financial Research, 23(1), 77-102.

Hall, C.M., Williams, A.M. (2008). Tourism and Innovation. London: Routledge. ISBN 978-0-415-41404-3.

Karaś, A., Pyrek, R. (2012). Relacje wynikające z wiedzy i ich rola w działalności innowacyjnej przedsiębiorstw. The Matopolska School of Economics in Tarnów Research Papers Collection, 21(2), 65-76. DOI: 10.25944/znmwse.2012.02.6576.

Kozioł, L., Wojtowicz, A., Karaś, A. (2017). The Concept of the Innovative Tourism Enterprises Assessment Capability. W: V. Katsoni, A. Upadhya, A. Stratigea (eds.). Tourism, Culture and Heritage in a Smart Economy. Springer Proceedings in Business and Economics. Cham: Springer, 159-172. DOI: 10.1007/978-3-319-47732-9_11.

Kozioł, L., Wojtowicz, A., Pyrek, R. (2014). Determinanty zdolności innowacyjnej przedsiębiorstw regionu Małopolski. Zeszyty Naukowe Małopolskiej Wyższej Szkoły Ekonomicznej w Tarnowie, 1(24), 113-122. DOI: 10.25944/znmwse.2014.01.113122.

Kuraś, P. (2012). Alians jako model współdziałania strategicznego przedsiębiorstw. W: A. Stabryła, T. Małkus (red.). Strategia rozwoju organizacji, 57-71. Kraków: Mfiles.pl. ISBN 978-83-931128-7-6.

Morris, D., Hergert, M. (1987). Trends in Collaborative Agreements. Columbia Journal of World Bussines, $22(2), 15-21$.

Morrison, M., Mezentseff, L. (1997). Learning Alliances - a New Dimension of Strategic Alliances. Management Decision, 35(5), 351-357.

Moszkowicz, M. (2000). Strategia przedsiębiorstwa okresu przemian. Warszawa: PWE. ISBN 83-208-1277-1.

Probst, G., Raub, S., Romhardt, K. (2004). Zarządzanie wiedza w organizacji. Kraków: Oficyna Ekonomiczna. ISBN 83-88597-77-9.

Romanowska, M. (1997). Alianse strategiczne przedsiębiorstw. Warszawa: PWE. ISBN 83-208-1063-9 .

Romanowska, M. (2017). Planowanie strategiczne w przedsiębiorstwie. Warszawa: PWE. ISBN 978-83208-2276-2.

Simonin, B.L. (1997). The Importance of Collaborative Know-how: An Empirical Test of the Learning Organization. Academy of Management Journal, 20, 1150-1174.

Sznajder, A. (2019). Alianse marketingowe na tle innych rodzajów aliansów, W: A. Sznajder (red.). Alianse marketingowe. Partnerstwa przedsiębiorstw dla zwiększenia konkurencyjności, 41-74. Warszawa: Wydawnictwo Nieoczywiste. ISBN 978-83-63391-78-2.

Von Hippel, Eric. (2016). Free Innovation. Cambridge MA: The MIT Press. ISBN 9780262035217.

Wojtowicz, A., Kozioł, L. (2012). Koncepcja aliansów wiedzy w procesie innowacji, Zeszyty Naukowe Małopolskiej Wyższej Szkoły Ekonomicznej w Tarnowie, 20(1), 211-223. DOI: 10.25944/znmwse.2012.01.211223.

Yoshino, M.,Y., Rangan, U.,S. (1995). Strategic Alliances - An entrepreneurial approach to globalization. Boston: Harvard Business School Press. ISBN 0-87584-584-3. 


\title{
Knowledge alliances and their impact on the innovative activity of the enterprise
}

\begin{abstract}
The aim of the article is to present the moi.e.: customers, competitors or cooperators and the relatives for concluding alliances between entities and an attempt to show their impact on the innovativeness and innovative activity of the enterprise. The first part of the article presents a discussion on the concepts related to innovation and the innovative potential of an enterprise, as well as the classification, features and goals of cooperation within strategic alliances. The article assumes that the innovative potential of an enterprise is a set of socio-economic features, shaped as part of the development of a given enterprise, constituting the basis for its innovative activity. The sectoral environment also has a strong impact on the innovativeness of the enterprise, tionships between them. The assessment of the degree of conducted innovative activity is the number of implemented innovations, the type of innovation or the values obtained from the innovations. The second part of the article presents the results of the analysis using the "case study" method. In the presented examples of enterprises, innovative activity is the result of effective cooperation with other entities by concluding alliances of joining forces or knowledge alliances. Due to alliances, enterprises have the opportunity to expand their own innovative potential, acquire knowledge necessary to create innovations and build a market position.
\end{abstract}

Keywords: knowledge alliances, innovations, innovative potential, capacity for innovation 